\title{
EFEKTIVITAS PENGGUNAAN MODEL PEMBELAJARAN TALKING STICK UNTUK MENINGKATKAN KEMAMPUAN MERESPON SISWA SEKOLAH DASAR
}

\author{
Ratih Wulandari \\ ratih.pooh@yahoo.com \\ Pendidikan Dasar Konsentrasi IPA Program Pascasarjana \\ Universitas Negeri Semarang
}

\begin{abstract}
This research was motivated by the difficulty of students in response to questions posed by the teacher that affects the outcome / student achievement. This study aims to improve science teaching in SDN Cibadak 1 Bandung, especially in class $V$ in the material circulation in humans by using model Talking Stick. This class action research took place in two cycles.And discussion of the results obtained some conclusions: First results obtained is an increased ability to respond to the students on the material circulation, in cycle 1 are $40.7 \%$ of students who have the ability to respond was good. In the second implementation cycle 2 is an improvement of cycle 1 and the ability to respond to students has increased. to 88.3\%. There was also an increase in student learning outcome in cycle 1 who meets the KKM amounted to $45 \%$ and in cycle 2 are $85.2 \%$. The conclusion of this study is the use of Talking Stick learning model can improve the ability to respond to students' science learning material circulation in class V SDN Cibadak 1. Thus the use of the learning model Talking stick can be used as an alternative learning approaches to be applied to learning science in schools Basic.
\end{abstract}

Keyword : Effectiveness, Talking Stick Learning Model, Response Capability

\begin{abstract}
ABSTRAK
Penelitian ini dilatar belakangi oleh sulitnya siswa dalam merespon pertanyaan yang diajukan oleh guru yang berpengaruh terhadap hasil / prestasi belajar siswa. Penelitian ini bertujuan untuk memperbaiki pembelajaran IPA di SDN Cibadak 1 Kota Bandung khususnya di kelas $\mathrm{V}$ pada materi peredaran darah pada manusia dengan menggunakan model pembelajaran Talking stick. Penelitian Tindakan kelas ini berlangsung dalam 2 siklus. Dari hasil dan pembahasan diperoleh beberapa kesimpulan: Pertama Hasil penelitian yang diperoleh yaitu adanya peningkatan kemampuan merespon siswa pada materi peredaran darah, pada siklus 1 terdapat 40,7\% siswa yang mempunyai kemampuan merespon yang baik. Kedua Pada pelaksanaan siklus 2 merupakan perbaikan dari siklus 1 dan
\end{abstract}


kemampuan merespon siswa mengalami peningkatan. menjadi 88,3\%. Selain itu juga adanya peningkatan hasil belajar siswa pada siklus 1 yang memenuhi KKM sebesar $45 \%$ dan pada siklus 2 terdapat $85,2 \%$. Kesimpulan dari penelitian ini adalah penggunaan model pembelajaran Talking stick dapat meningkatkan kemampuan merespon siswa pada pembelajaran IPA materi peredaran darah di kelas V SDN Cibadak 1. Dengan demikian penggunaan model pembelajaran Talking stick dapat dijadikan sebagai salah satu alternatif pendekatan pembelajaran untuk diterapkan pada pembelajaran IPA di Sekolah Dasar.

Kata Kunci : Kemampuan Merespon, Model Pembelajaran Talking stick. Peredaran darah manusia

\section{A. PENDAHULUAN}

Masalah yang melatarbelakangi penelitian ini adalah seringnya ditemukan kesulitan yang dialami guru dalam proses pengembangan pembelajaran khususnya mata pelajaran IPA di sekolah dasar. Penelitian ini juga dilatar belakangi oleh sulitnya siswa dalam merespon pertanyaan yang diajukan oleh guru yang berpengaruh terhadap hasil / prestasi belajar siswa. Respon yang baik sangat penting dimiliki oleh siswa, agar pembelajaran dapat berlangsung dengan lancar dan adanya komunikasi multi arah antara guru dan siswa.

Menurut kamus besar bahasa Indonesia respon berasal dari kata response, yang berarti balasan atau tanggapan (reaction). Menurut Sarlito, (1995) respon adalah Setiap tingkah laku pada hakekatnya merupakan tanggapan atau balasan (respon) terhadap rangsangan atau stimulus. Menurut Gulo (1996), respon adalah suatu reaksi atau jawaban yang bergantung pada stimulus atau merupakan hasil stimulus tersebut. Respon juga di artikan sebagai suatu tingkah laku atau sikap yang berwujud baik atau penolakan, suka atau tidak suka serta pemanfaatan pada suatu fenomena tertentu (Sobur, 2003). Jadi dapat disimpulkan bahwa respon adalah tanggapan atau jawaban atas stimulus/pertanyaan yang diberikan, yang dapat berbentuk positif/jawaban benar dan juga negatif/jawaban 
salah. Respon positif siswa dalam pembelajaran merupakan suatu keberhasilan yang ingin dicapai oleh seorang guru dalam proses pembelajaran di sekolah dasar.

Menurut Thorndike, dasar dari belajar itu adalah asosiasi antara kesan panca indra (sense impression) dengan impuls untuk bertindak (impuls to action). Asosiasi yang demikian ini dinamakan "connecting". Dengan kata lain, belajar adalah pembentukan hubungan antara stimulus dan respon, antara aksi dan reaksi. Antara stimulus dan respon ini akan terjadi suatu hubungan yang erat kalau sering dilatih. Berkat latihan yang terus-menerus, hubungan antara stimulus dan respons itu akan menjadi terbiasa, otomatis.

Berdasarkan latar belakang permasalahan di atas maka peneliti mengangkat judul penelitian tindakan kelas "efektivitas penggunaan model pembelajaran talking stick untuk meningkatkan kemampuan merespon siswa pada materi peredaran darah manusia"

Berdasarkan latar belakang permasalahan di atas maka peneliti mengangkat judul penelitian tindakan kelas "efektivitas penggunaan model pembelajaran talking stick untuk meningkatkan kemampuan merespon siswa pada materi peredaran darah manusia"

\section{B. METODOLOGI PENELITIAN}

Dalam penelitian ini, metode yang digunakan adalah metode penelitian tindakan kelas (PTK). Hopkins dalam Muslich (2009:8) mengungkapkan bahwa "Penelitian tindakan kelas adalah suatu bentuk kajian yang bersifat reflektif, yang dilakukan oleh pelaku tindakan untuk meningkatkan kemantapan rasional dari tindakan-tindakan dalam melaksanakan tugas dan memperdalam pemahaman terhadap kondisi dalam praktik pembelajaran". Arikunto (2009:3) dalam buku yang berjudul Penelitian Tindakan Kelas, mengungkapkan bahwa penelitian tindakan kelas adalah "Suatu pencermatan terhadap kegiatan belajar berupa sebuah tindakan, yang sengaja dimunculkan dan terjadi dalam sebuah kelas secara bersama."

\begin{tabular}{llr}
\multicolumn{1}{c}{ Pada } & tahap & pelaksanaan \\
tindakaan, & kegiatan & penelitian \\
dilaksanakan & & berdasarkan
\end{tabular}


perencanaan tindakan yang telah ditetapkan, yaitu melaksanakan pembelajaran sesuai rencana pembelajaran yang telah dibuat. Fokus tindakan adalah penggunaan model pembelajaran Talking Stick yang dioptimalkan untuk meningkatkan kemampuan merespon siswa, khususnya materi peredaran darah pada manusia. Pada tahap pelaksanaan tindakan ini, proses pembelajaran dilaksanakan dengan menjalankan skenario pembelajaran yang telah dirancang dan terdapat dalam RPP, dan yang bertugas sebagai guru adalah kita sendiri,sedangkan guru kelas pada saat penelitian ini bertugas sebagai peneliti/pengamat kegiatan yang dilakukan oleh guru.

Data-data yang dibutuhkan untuk kebutuhan penelitian dikumpulkan dengan menggunakan cara-cara yang sekiranya tepat dan mendukung dalam penelitian tindakan kelas tersebut. Cara pengumpulan data yang digunakan pada penelitian tindakan kelas ini adalah sebagai berikut.Observasi,Wawancara,Tes.

Angket. Memasukkan data ke dalam rumus statistik sederhana, yaitu mean (rata-rata skor) dengan rumus:

$$
\begin{aligned}
& \bar{x}=\frac{\mathrm{F} \mathrm{x} \mathrm{bobot}}{n} \times 100 \% \\
& \bar{x}=\text { Rata-rata skor., } \mathrm{F}
\end{aligned}
$$

\section{HASIL DAN PEMBAHASAN}

Berdasarkan tindakan yang telah dilaksanakan pada siklus I dan II pada pembelajaran IPA dengan menggunakan model pembelajaran talking stick untuk meningkatkan kemampuan merespon siswa kelas $\mathrm{V}$ dalam materi peredaran darah pada manusia yaitu dijelaskan sebagai berikut.

1. Perencanaan pembelajaran dengan menggunakan model pembelajaran talking stick

Agar model pembelajaran talking stick dapat diimplementasikan dalam proses pembelajaran, maka terlebih dalam perlu dibuat rancangan pembelajaran yang berisi strategi pembelajaran materi peredaran darah. Penyusunan perangkat pembelajaran yang dilakukan adalah penyusunan silabus yang kemudian dijabarkan dalam rencana 
pelaksanaan pembelajaran (RPP). Perencanaan yang matang dibutuhkan untuk menciptakan proses pembelajaran yang berkualitas baik. Setiap guru sebelum melaksanakan kewajibannya di kelas, wajib menyusun RPP secara lengkap dan sistematis agar pembelajaran berlangsung secara sistematis, terarah, menyenangkan, memotivasi peserta didik untuk berpartisipasi aktif, serta memberikan ruang yang cukup bagi kreativitas dan sesuai dengan bakat, minat, dan perkembangan fisik serta psikologi peserta didik.

Dalam penelitian tindakan kelas ini, kualitas RPP yang dibuat diukur dengan menggunakan rubrik penilaian RPP. Setiap butir rencana kegiatan yang tertuang dari RPP dinilai oleh observer berupa komentar atau catatan-catatan penting. Penilaian RPP dilihat dari 6 aspek yang sesuai dengan rubrik penilaian RPP, yang terdiri dari: a) tujuan; b) langkah pembelajaran; c) materi pokok; d) sumber, media dan alat; e) penilaian, dan f) alokasi waktu.

a. Kualitas Rencana Pelaksanaan Pembelajaran (RPP) Siklus I
Setelah menganalisis kualitas RPP yang dibandingkan dengan rubrik penilaian RPP, selanjutnya melakukan

pengkategorian berdasarkan persentase yang didapat. Observer menyatakan bahwa kualitas RPP siklus I dari segi perencanaan masuk dalam kategori BAIK. menurutnya RPP yang dibuat peneliti memenuhi semua komponen dan telah sesuai dengan rubrik penilaian RPP, namun dari segi pelaksanaannya terdapat beberapa kekurangan sehingga beberapa komponen tersebut memiliki kategori BAIK.

b. Kualitas Rencana Pelaksanaan Pembelajaran (RPP) Siklus II

Kualitas RPP siklus II baik dari segi perencanaan maupun pelaksanaan telah menunjukkan peningkatan dibandingkan dengan kualitas RPP siklus I, menurut observer kualitas RPP siklus II adalah masuk dalam kategori SANGAT BAIK. Sehingga bila dibandingkan dengan indikator keberhasilan dalam penelitian ini, maka dapat dikatakan bahwa kualitas RPP yang disusun telah berhasil (berkualitas sangat baik). 
Menurut Permendiknas No. 41 Tahun 2007 yang menyatakan bahwa: "Perencanaan proses pembelajaran meliputi silabus dan rencana pelaksanaan pembelajaran (RPP) yang memuat identitas mata pelajaran, standar kompetensi (SK), kompetensi dasar (KD), indikator pencapaian kompetensi, tujuan pembelajaran, materi ajar, alokasi waktu, metode pembelajaran, kegiatan pembelajaran, penilaian hasil belajar, dan sumber belajar"

Dapat disimpulkan bahwa penilaian RPP pada siklus I belum mempunyai kualitas baik secara keseluruhan sesuai dengan teori yang dikemukakan Permendiknas No.41 Tahun 2007, akan tetapi pada siklus 2 terdapat peningkatan kualitas RPP sehingga RPP yang dibuat sudah sesuai dengan teori di atas.

\section{Ketercapaian pelaksanaan} pembelajaran materi peredaran darah dengan menggunakan model talking stick

Pelaksanaan pembelajaran merupakan impelementasi dari RPP yang telah disusun. Pelaksanaan pembelajaran pada umumnya meliputi kegiatan pendahuluan, kegiatan inti dan kegiatan penutup.
Pada tahap ini serangkaian strategi dan skenario pembelajaran yang telah disusun berusaha untuk diimplementasikan oleh peneliti dengan sebaik mungkin agar tujuan yang diinginkan dapat tercapai secara cepat dan tepat. Implementasi pembelajaran yang dilakukan paneliti dari siklus I sampai dengan siklus II menggunakan model pembelaaran talking stick. Model pembelajaran ini mengoptimalkan siswa untuk terlibat secara aktif dan memudahkan siswa untuk memahami materi.

Implementasi pembelajaran materi peredaran darah dengan menggunakan model pembelajaran talking stick, berikut ini akan dibahas satu persatu dari setiap siklusnya.

a. Ketercapaian pelaksanaan RPP Siklus I

Berdasarkan analisis data tentang pengamatan terhadap proses ketercapaian pelaksanaan RPP siklus I, maka menurut observer dari 24 komponen yang diamati, pelaksanaannya muncul sebanyak 17 komponen saja (70,8\%). Dengan demikian bila dikategorikan, pelaksanaan RPP dalam pembelajaran siklus I masuk dalam kategori BAIK. Namun, pelaksanaan 
RPP pada pembelajaran siklus I belum tercapai secara keseluruhan.

b. Ketercapaian pelaksanaan RPP Siklus II

Hasil analisis data tentang pengamatan terhadap proses ketercapaian pelaksanaan RPP, maka menurut observer bahwa seluruh komponen pada lembar observasi proses pembelajaran yang berjumlah 24 komponen menunjukkan peningkatan pelaksanaannya muncul sebanyak 24 komponen (100\%) setiap komponen muncul dan terlaksana dengan baik, guru mengikuti saran dan kritik dari observer untuk melakukan perbaikanperbaikan.

Dengan demikian, ketercapaian pelaksanaan pembelajaran siklus II dinyatakan berhasil secara keseluruhan dan mempunyai kategori Sangat Baik dengan nilai presentase mencapai $100 \%$.

Menurut Permendiknas No. 41 Tahun 2007 yang menyatakan bahwa "Pelaksanaan pembelajaran merupakan implementasi dari RPP. Pelaksanaan pembelajaran meliputi kegiatan pendahuluan, kegiatan inti dan kegiatan penutup".
Dapat disimpulkan bahwa penilaian pelaksanaan RPP pada siklus I belum terlaksana baik secara keseluruhan sesuai dengan teori yang dikemukakan Permendiknas No.41 Tahun 2007, akan tetapi pada siklus 2 terdapat peningkatan kualitas pelaksanaan RPP sehingga dapat sesuai dengan teori yang ada.

\section{Pencapaian Hasil Belajar Siswa} Segi Kognitif, Afektif, dan Psikomotor.

Untuk mengetahui hasil pencapaian dan peningkatan kemampuan merespon pada siswa, dalam hal ini adalah kemampuan merespon, kemampuan berfikir logis dan kritis, peneliti melakukan penilaian berdasarkan hasil belajar siswa (aspek kognitif) dalam bentuk soal tes (pre-tes dan post-tes), penilaian berdasarkan pada aspek afektif dan aspek psikomotor dalam bentuk lembar pengamatan.

Berdasarkan wawancara dan observasi awal terhadap proses pembelajaran IPA materi peredaran darah pada manusia di kelas $\mathrm{V}$ SDN Cibadak 1, ditemukan fakta tentang rendahnya kemampuan merespon siswa terhadap pertanyaan yang diberikan oleh guru. Rendahnya 
kemampuan tersebut terjadi salah satunya disebabkan oleh faktor guru yang menggunakan metode konvensional tanpa menggunakan media pembelajaran yang tepat, sehingga siswa hanya pasif mendengarkan penjelasan dari guru serta siswa tidak memiliki kesempatan untuk mencari dan menemukan konsepnya sendiri terhadap materi pelajaran.

Berawal pada permasalahan di atas, maka peneliti terdorong untuk meningkatkan kemampuan merespon siswa dalam pembelajaran yaitu dengan menggunakan model pembelajaran talking stick.

Berdasarkan analisis data menunjukan perkembangan aspek kognitif mengalami peningkatan, hal ini tampak dari peningkatan hasil pretest ke pos-test di siklus I dari 18,5\% jumlah siswa yang mencapai ketuntasan belajar setelah ditindak dengan menggunakan model pembelajaran talking stick menjadi 45 \% siswa yang mencapai ketuntasan. Dengan demikian model pembelajaran talking stick meningkatkan hasil belajar.

Hasil Post-test pun mengalami peningkatan yang signifikan dari siklus I ke siklus II. Pada siklus Isiswa yang telah tuntas mencapai KKM sebanyak 12 orang dari jumlah siswa 27 orang (45\%). Sedangkan pada siklus 2 siswa yang mencapai KKM sebanyak 23 orang $(85,2)$. Dengan demikian, dapat dipastikan bahwa model pembelajaran talking stick mampu mengubah pola pikir siswa sehingga dapat meningkatkan hasil belajar dalam aspek kognitif secara signifikan dan model ini dipandang bermanfaat dan bermakna.

Untuk dapat dilihat gambaran secara jelas tentang peningkatan hasil belajar siswa melalui post-test pada siklus I dan siklus II sajikan pada grafik berikut:

Pencapaian nilai post-test siswa tiap siklusnya mengalami peningkatan setelah menggunakan model pembelajaran talking stick, ini sesuai dengan teori yang dikemukakan oleh Maehr (Suryabrata 2001:45) yang menyatakan bahwa "Hasil belajar peserta didik dapat diukur berdasarkan perubahan perilaku sebelum dan sesudah belajar dilakukan", dan bila dibandingkan dengan indikator keberhasilan penelitian tindakan kelas ini, maka nilai post-test siswa 
pada penelitian ini sudah mencapai target dan penelitian dapat dikatakan berhasil.

Selain itu, berdasarkan analisis data hasil pengamatan terhadap aspek afektif dan aspek psikomotor, diketahui bahwa dari siklus I sampai dengan siklus II, perilaku yang terkait aspek afektif dan aspek psikomotor siswa telah memiliki peningkatan. Pada siklus I, perilaku yang mencerminkan aspek afektif siswa masih belum sempurna. Kekurangan masih terdapat pada beberapa siswa yang belum menunjukkan perubahan perilaku afektif tertentu yang diamati. Namun pada siklus II, sebagian besar siswa telah mampu menunjukkan sikap-sikap afektif yang diamati secara baik.

Sedangkan untuk aspek psikomotor, pada siklus I, siswa belum mampu melakukan aktivitasaktivitas psikomotor yang diamati. Namun pada siklus II, seluruh siswa telah mampu melakukan seluruh aktivitas psikomotor yang diamati secara baik.

Pada proses awal pembelajaran kemampuan merespon siswa terhadap pertanyaan guru sangat kurang, ini dapat dilihat pada siklus 1 hanya sebagian kecil saja siswa yang dapat merespon pertanyaan dengan baik sesuai dengan indicator yaitu sebesar $40,7 \%$, namun pada siklus 2 kemampuan merespon siswa meningkat menjadi $88,3 \%$, ini membuktikan bahwa model pembelaaran talking stick sangat cocok digunakan dalam proses pembelajaran karena dapat meningkatkan kemampuan merespon siswa yang dapat berdampak pada hasil akhir belajar, apabila kemampuan merespon siswa meningkat, maka secara otomatis hasil belajarnya pun meningkat. Untuk lebih jelasnya dapat dilihat di diagram dibawah ini :

Menurut pendapat Gulo (1996), "Respon adalah suatu reaksi atau jawaban yang bergantung pada stimulus atau merupakan hasil stimulus tersebut", maka sejalan pendapat tersebut kemampuan merespon siswa sangat bergantung pada stimulus yang diberikan, berdasarkan diagram di atas kemampuan merespon siswa terhadap pembelajaran meningkat setiap siklusnya yang diakibatkan adanya rangsangan atau stimulus 
yang meningkat dengan penggunaan model pembelajaran talking stick.

\section{Hasil Angket Respon Siswa}

Angket respon digunakan untuk mengetahui tanggapan siswa dalam pembelajaran IPA materi peredaran darah pada manusia dengan menggunakan model pembelajaran talking stick. Respon siswa tersebut dapat diukur dengan butir-butir pernyataan yang harus direspon siswa.

Berdasarkan hasil analisis data angket respon siswa, diketahui bahwa respon siswa terhadap pembelajaran pada penelitian siklus I sampai dengan siklus II mengalami peningkatan, yaitu dari 8 item angket yang direspon pada siklus I mencapai sebesar $73 \%$ yang direspon dengan pernyataan YA atau yang berarti setuju. Sedangkan pada penelitian siklus II, terjadi peningkatan yaitu menjadi 83\% angket direspon oleh siswa dengan pernyataan $Y A$.

Menurut Sobur, (2003) "Respon di artikan sebagai suatu tingkah laku atau sikap yang berwujud baik atau penolakan, suka atau tidak suka serta pemanfaatan pada suatu fenomena tertentu". Maka berdasarkan diagram di atas, adanya peningkatan respon siswa terhadap pelaksanaan pembelajaran dengan menggunakan model pembelajaran talking stick dari siklus I ke siklus II yang sesuai dengan teori yang dikemukakan sebelumnya.

\section{KESIMPULAN}

Pada siklus ke-1 tingkat kemamuan merespon siswa rata-rata dalam proses pembelajaran adalah $40,7 \%$ atau memiliki kategori cukup baik. Pada siklus ke-2 tingkat kemamuan merespon siswa rata-rata dalam proses pembelajaran adalah $70,8 \%$ atau memiliki kategori baik.

Selain itu hasil evaluasi siswa juga terus mengalami peningkatan pada siklus 1 dan siklus 2 diperoleh data sebagai berikut:

Pada siklus 1 hasil pretes sebagai berikut dari sebanyak siswa di kelas $\mathrm{V}$ (27 orang) ternyata 5 orang $(18,5 \%)$ sudah mencapai nilai KKM. dan sisanya 22 orang (81,5\%) belum tuntas mencapai KKM. Sedangkan pada hasil pos-test menunjukan bahwa sebanyak 12 orang (45\%) telah mencapai nilai minimal KKM, dan yang belum mencapai nilai KKM adalah sebanyak 15 orang (55\%). 
Pada siklus 2 hasil pretes sebagai berikut dari 14 orang $(51,8 \%)$ sudah mencapai nilai KKM. dan sisanya 13 orang $(48,2 \% \%)$ belum tuntas mencapai KKM. Sedangkan pada hasil post-test menunjukan bahwa sebanyak 23 orang $(85,2 \%)$ telah mencapai nilai minimal KKM. Akan tetapi masih ada yang belum mencapai nilai minimal KKM adalah sebanyak 4 orang (14,8\%).

Kemudian implementasi RPP dalam KBM pada Siklus I memiliki persentase sebesar $70,8 \%$ atau memiliki kategori baik. Pada Siklus 2 persentasenya sebesar $91 \%$ atau memiliki kategori sangat baik.

\section{DAFTAR PUSTAKA}

A.M.,Sardiman. (2011). Interaksi dan Motivasi Belajar-Mengajar. Jakarta : RajaGrafindo Persada

Ariefianto. (2007). IImu Pengetahuan Alam untuk Siswa SD-MI Kelas V. Bandung : Karya Media Utama Arikunto,Suharsimi,. (2012). Dasardasar Evaluasi Pendidikan. Jakarta : Bumi Aksara

Depdiknas. (2006). Kurikulum Tingkat Satuan Pendidikan Sekolah Dasar Mata pelajaran IPA SD/MI. Jakarta : Depdiknas
Haryanto. (2007). Sains untuk Kelas VSD. Jakarta : Erlangga

Mulyasa, (2011). Praktik Penelitian Tindakan kelas. Bandung : Rosda Mulyono,Yoyo. (2000). Keefektifan Model Mengajar Respons Pembaca dalam Pengajaran Pengkajian Puisi. Bandung : Desertasi UPI (Tidak diterbitkan)

Nasution. (2011). Berbagai

Pendekatan dalam Proses Belajar dan Mengajar. Jakarta : Bumi Aksara

Pribadi,Benny.(2011). Model Assure untuk Mendesain Pembelajaran Sukses. Jakarta : Dian Rakyat Sudjana,Nana dan Wari Suwariyah. (2010). Model-model Mengajar CBSA. Bandung : Sinar Baru Algensindo

Trianto. (2011). Model-model Pembelajaran Terpadu. Jakarta : Bumi Aksara

Uno,Hamzah.,Dkk. (2011). Menjadi Peneliti PTK yang Profesional. Jakarta : Bumi Aksar

Winataputra, S, U, dkk. (2005). Strategi Belajar Mengajar. Jakarta : Universitas Terbuka 